\title{
Pelatihan Pengembangan Pemasaran Secara Daring Pada Budidaya Ikan Koi Blitar
}

\author{
Online Marketing Development Training On Koi Fish In Blitar
}

\author{
Harliana*1, Roby Setiadi² $^{2}$ Otong Saeful Bachri ${ }^{3}$, Khalid Iskandar ${ }^{4}$, Gian Fitralisma ${ }^{5}$, \\ R.M.Herdian Bhakti ${ }^{6}$ \\ ${ }_{1,3,6}$ Program Studi Teknik Informatika, Fakultas Teknik, Universitas Muhadi Setiabudi, Indonesia \\ ${ }^{2,4,5}$ Program Studi Manajemen, Fakultas Ekonomi dan Bisnis, Universitas Muhadi Setiabudi, Indonesia \\ e-mail: *1harliana@umus.ac.id, ${ }^{2}$ robysetiadi@umus.ac.id, ${ }^{3}$ otongsb@umus.ac.id, \\ ${ }^{4}$ khalidiskandar@umus.ac.id, ${ }^{5}$ gian@umus.ac.id, ${ }^{6}$ bhakti@umus.ac.id
}

\begin{abstract}
Abstrak
Mubin Koi merupakan salah satu pembudidaya Ikan koi Blitar yang membudidayakan jenis koi kontes dan koi peternak. Sejak pandemic covid-19, penjualan koi mengalami penurunan drastis. Berbagai promosi yang telah dilakukan baik melalui media social ataupun offline masih dirasakan stagnan. Berdasarkan permasalahan tersebut maka pada kegiatan pengabdian ini, kami mencoba untuk membantu Mubin Koi dalam menganalisa strategi pemasaran yang dilakukan melalui proses segmentation, targeting dan positioning terhadap jenis koi yang dimiliki Mubin Koi. Selama kurun waktu 1 bulan kegiatan, dihasilkan bahwa segementasi pasar jenis kontes lebih ditujukan ke kota-kota besar karena tergetting dari segementasi ini adalah para pecinta ikan hias, sedangkan untuk koi peternak, target dari segmentasi pasarnya adalah daerah dengan jumlah pembudidaya ikan koi yang besar. Selain itu dilakukan pula pelatihan pembuatan catalog terhadap admin untuk mendukung segmentasi secara online. Kata kunci-ikan koi, segemenatasi pasar, promosi
\end{abstract}

\begin{abstract}
Mubin Koi is one of the Blitar koi fish farmers who cultivates contest koi and breeder koi. Since the Covid-19 pandemic, koi sales have decreased. Various promotions that have been carried out both through social media and offline are still felt to be stagnant. Based on these problems, this activity tries to assist Mubin Koi in analyzing the marketing strategy carried out through the process of segmentation, targeting and positioning of the types of koi in Mubin Koi. During the period of 1 month of activity, it resulted that the contest-type market segmentation was aimed more at big cities because the target of this segmentation was fish hobbyists, while for koi breeders, the target of the market segmentation was areas with a large number of koi fish cultivators. In addition, training on making a catalog for admins was also conducted to support online segmentation.
\end{abstract}

Keyword — koi fish, market segmentation, promotion

\section{PENDAHULUAN}

Kota Blitar atau yang biasa disebut sebagai kota Patria merupakan kota terkecil kedua di Jawa Timur yang hanya memiliki luas 32,58 $\mathrm{km}^{2}$ (Pemerintah Kota Blitar, 2019). Meskipun kota kecil, namun Blitar memiliki beberapa produk unggulan yang telah mampu menembus pasar Internasional diantaranya adalah kerajinan batok, batik khas blitar, dan buah belimbing (Pemerintah Kota Blitar, 2020). Selain 3 produk tersebut, produk lain yang menjadi ciri khas Blitar diantaranya Kendang Sentul, wajik kletik, ikan koi, kerajinan batu onix (sand stone), sambel pecel, gambol kayu jati, gula merah / gula kelapa(Albab, 2012). Pada tahun 2015, budidaya ikan koi dan kendang jimbe Blitar mampu menembus pasar internasional. Untuk kendang jimbe, produksinya mampu menembus pasar China, Taiwan, dan Eropa(Harliana et al., 2020). Sedangkan untuk ikan koi mampu menempus pasar Malaysia, Taiwan, dan Autralia.

Mubin Koi Farm merupakan salah satu pembudidaya ikan koi di Blitar, dimana jenis koi kontes yang dibudidayakan diantaranya Showa, Benigningga, Marakuten Kohaku Doitsu, Sanke Aka Matsuba dan lainnya. Karena Mubin Koi Farm adalah pembudidaya untuk jenis koi kontes dan koi peternak maka ada beberapa jenis indukan koi yang berhasil disilangkan dengan koi lokal

Submitted: Januari 2021, Accepted: Februari 2021, Published: Februari 2021

ISSN 2746-6345 (media online) 
grade A, B, dan C. Hal ini bertujuan untuk mendapatkan varians jenis koi baru dengan harga yang lebih murah namun tidak merubah kualitas warna, corak dan panjang koi yang dihasilkan. Koi-koi jenis persilangan ini selanjutnya dipisahkan berdasarkan gradenya kedalam kolam berbeda. Gambar 1 merupakan jenis kolam berdasarkan grade koi yang dihasilkan.

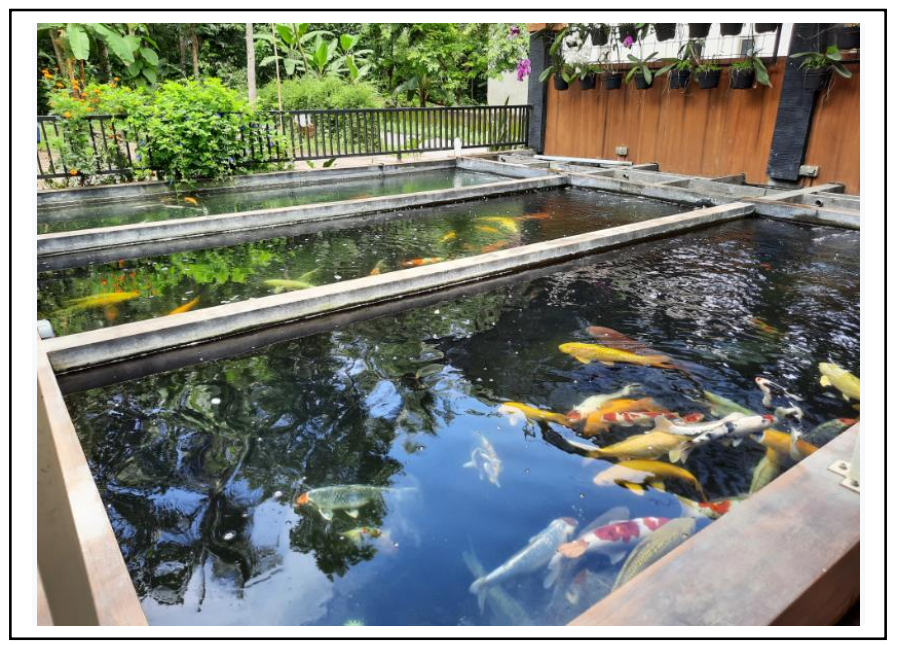

Gambar 1. Kolam sesuai grade

Sejak tahun 2016 sampai dengan 2019, untuk setiap bulannya Mubin Koi Farm berhasil menjual minimal 4 ekor jenis showa ke Vietnam, Malaysia dan Singapura dengan harga US\$6.700 atau setara dengan Rp.95.145.360. Namun sejak adanya Pandemi Covid-19 di bulan Februari 2020 penjualan koi menurun tajam. Tercatat sejak Februari sampai dengan Agustus 2020 Mubin Koi Farm hanya mampu menjual 4 ekor koi jenis Sanke dengan harga US\$50 yang setara dengan Rp.700.000. Untuk meningkatkan penjualan, maka pada bulan April 2020 Mubin Koi Farm mulai memasarkan koi-koi tersebut melalui Instagram dengan nama nestkoi seperti Gambar 2. Namun sistem pemasaran seperti ini masih dirasakan belum optimal dan penjualan koi pun masih stagnan.

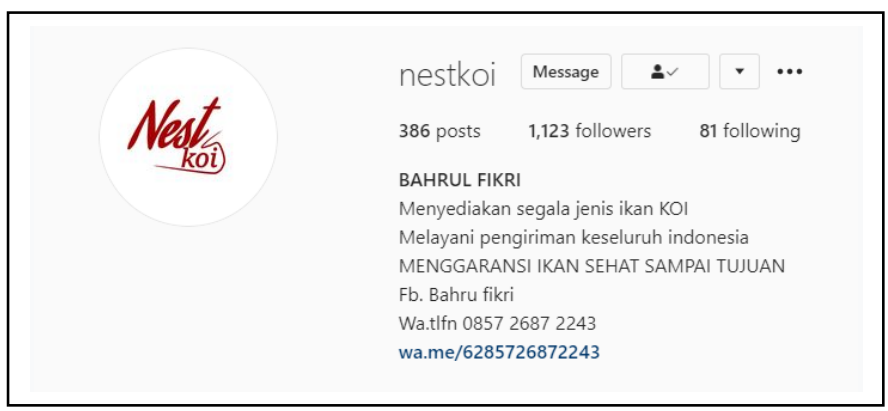

Gambar 2. Pemasaran yang dilakukan saat ini

Berdasarkan hal tersebut, maka permasalahan yang ditemukan pada mitra PKM kali ini adalah masih belum optimalnya sistem pemasaran yang dilakukan oleh Mubin Koi Form baik melalui daerah pemasaran ataupun Instagram, selain itu belum adanya katalog serta kurang menariknya promosi yang dilakukanpun masih menjadi kendala tersendiri. Melihat permasalahan tersebut, maka solusi yang ditawarkan adalah:

1. Pelu dilakukannya arah segmentasi pasar untuk jenis koi yang dibudidayakan. Baik untuk jenis koi kontes / hobi dan koi ternak.

2. Perlu adanya katalog digital untuk mempermudah customer dalam mengelompokkan jenis koi yang diinginkan. 
Beberapa penelitian terdahulu yang penulis jadikan referensi dalam menentukan solusi adalah dalam melakukan strategi pemasaran yang baik ternyata perlu dilakukkannya proses segmentasi pasar, targeting dan positioning yang tepat sasaran dalam menaikkan total penjualan (Oktaviandi, 2020). Dalam melakukan segmentasi pasar dapat dilakukan melalui pendekatan segmentasi demografis dan segmentasi geografis, sedangkan untuk targeting dapat dilakukan melalui evaluasi daerah yang akan dituju sebagai sasaran penjualan produk (Hakiki, 2020). Untuk mendapatkan hasil yang lebih maksimal dan mencapai semua lapisan maka kegiatan STP (segmenting, targeting, dan positioning) dapat diterapkan melalui media social seperti Instagram melalui pengoptimalan fitur Social Media Optimization (SMO) (Abdullah et al., 2020). Dalam menerapkan digital marketing, beberapa keuntungan yang dapat diperoleh perusahaan diantaranya praktisnya sistem pemasaran yang dilakukan, mengurangi beban operasional, serta dapat lebih cepat dalam merespon customer(Putri \& Saifuddin, 2020). Manfaat lain yang didapat saat melakukan pemasaran melalui media sosial diantaranya dapat melihat respon customer terhadap produk apakah perlu dipertahankan bahkan ditingkatkan sehingga dapat segera dilakukan perbaikan untuk solusi yang diperlukan(Sadiyah et al., 2020). Untuk mendukung promosi yang dilakukan, maka penggunaan katalog produk baik secara online ataupun offline, dimana penggunaan katalog ini bersifat sederhana tetapi langsung menuju sasaran (to the point) terhadap maksud dan tujuan yang ingin disampaikan(Rozsidhy \& Pribadi, 2018). Pembuatan e-katalog melalui website juga ternyata dapat membantu meningkatkan omset penjualan di bulan ke-3 penerapan (Bukit et al., 2019). Berdasarkan beberapa referensi diatas, maka solusi yang kami tawarkan dalam kegiatan pengabdian ini adalah membantu mubin koi dalam melakukan segmentasi pasar terhadap jenis ikan yang dibudidayakan baik melalui media social ataupun segmentasi pasar langsung. Selain itu untuk memperkuat promosi yang dilakukan, maka pada kegiatan pengabdian ini juga akan dilakukan pelatihan desain dengan menggunakan coreldraw, hal ini bertujuan untuk melatih dan memberikan pengetahuan kepada pegawai untuk dapat mendesain catalog yang menarik untuk para customer.

\section{METODE PELAKSANAAN}

Pada kegiatan PKM ini, dimulai dengan analisis terhadap permasalahan mitra yaitu sistem pemasaran melalui media internet, selanjutnya permasalahan tersebut akan dianalisis untuk mendapatkan solusi yang tepat. Berdasarkan beberapa literatur maka solusi yang ditawarkan adalah perlu dilakukannya segementasi pasar baik secara geografis, demografis ataupun psikografis mengenai penjualan koi jenis kontes dan ternak baik secara offline ataupun online melalui berbagai media sosial. Selain itu perlu juga dilakukannya targeting dan positioning terhadap strategi pemasaran yang akan dilakukan. Solusi lain yang ditawarkan juga berupa adanya pelatihan terhadap pembuatan katalog digital yang diharapkan dapat mempermudah customer dalam memilih koi berdasarkan jenisnya.

Semua kegiatan ini selanjutnya akan diimplementasikan dalam jangka waktu 1 bulan yaitu sejak tanggal 10 September sampai dengan 12 Oktober 2020 yang bertempat di Mubin Koi Farm Desa Sumber Kecamatan Sanankulon Kabupaten Blitar.

Sebagai tolak ukur keberhasilan atas solusi yang diberikan maka kami akan melakukan evaluasi berupa:

1. Peningkatan jumlah pemesanan selama kurun waktu 2 bulan.

2. Pemahaman mitra terhadap pembuatan desain katalog digital yang menarik.

Rangkuman mengenai tahapan pelaksanaan kegiatan PKM ini terdapat pada Gambar 3. Karena kegiatan ini bersifat multi disiplin, maka tim pada kegiatan ini terdiri dari para dosen Program Studi Ekonomi Fakultas Ekonomi dan Bisinis serta para dosen Program Studi Teknik Informatika Fakultas Teknik Universitas Muhadi Setiabudi.

Untuk kegiatan perencanaan strategi pemasaran secara digital marketing akan lebih dominan dilakukan oleh para dosen dari Program Studi Ekonomi yang akan berdiksusi langsung dengan

Online Marketing Development Training on Koi Fish in Blitar (Harliana, Roby Setiadi, Otong Saeful Bachri, Khalid Iskandar, Gian Fitralisma, R.M.Herdian Bhakti) 
Bapak Mubin selaku pemilik dari Mubin Koi Farm dengan melihat beberapa data penjualan selama kurun waktu 2016 sampai dengan 2020. Sedangkan untuk kegiatan pelatihan pembuatan desain katalog digital akan didampingi oleh dosen dari Program Studi Teknik Informatika melalui pelatihan penggunaan coreldraw dan canva.

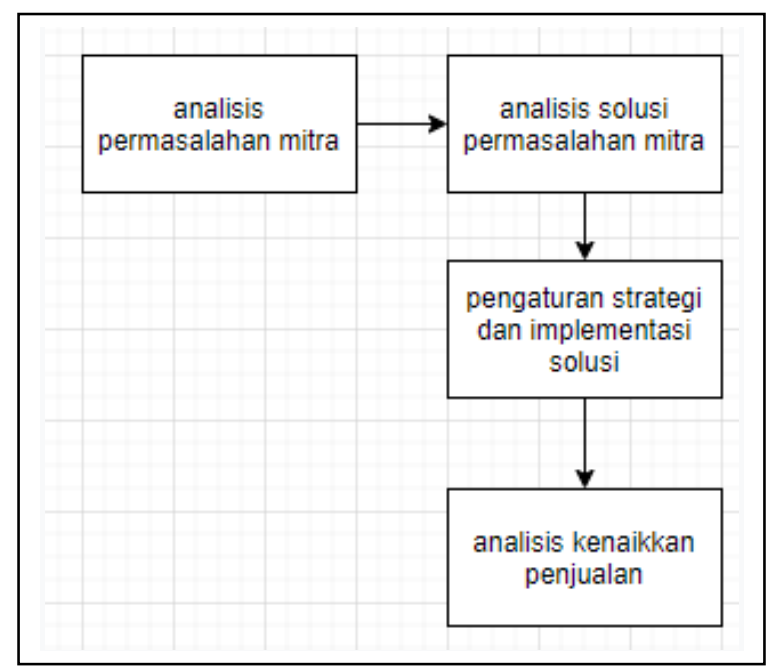

Gambar 3. Tahapan kegiatan

\section{HASIL DAN PEMBAHASAN}

Berdasarakan analisa terhadap permasalahan yang terjadi, analisis terhadap pasar dimulai dengan penentuan segmentasi pasar, kemudian identifikasi terhadap target pasar, serta identifikasi posisi Mubin Koi Farm terhadap para pesaingnya.

\section{Market segmentation}

Untuk kegiatan segmentasi pasar, penjualan koi akan dibagi menjadi segmentasi pasar kelas kontes dan segmentasi pasar kelas ternak, sebagai berikut:

a. Segmentasi pasar koi kelas kontes/hobi

Apabila dilihat dari data penjualan, maka untuk jenis kelas kontes segmentasi geografis yang dapat dilakukan adalah kegiatan promosi yang akan ditujukan ke wilayah perkotaan besar di Indonesia yaitu Malang, Surabaya, Semarang, Jakarta, Bandung, Bogor, dan Palembang. Hal ini dilihat berdasarkan riwayat pemesanan selama kurun waktu tahun 2017-2018 dimana custumer paling banyak berasal dari Kota Malang, Surabaya, Jakarta dan Palembang. Sedangkan untuk Kota Bandung, Bogor, dan Semarang dipilih karena kota-kota ini biasa mengadakan kontes ikan hias selama kurun waktu tahun 2020. Sedangkan untuk luar negeri segmentasi geografis bisa mentargetkan negara Vietnam dan Malaysia.

Dari sisi segmentasi demografis, Mubin Koi Farm akan mentargetkan para penghobi ikan hias khususnya ikan koi di seluruh dunia, namun secara psikografis maka jenis koi kontes hanya diperutukkan bagi masyarakat kalangan atas yang menjadikan ikan koi sebagai hobi dan koleksi pribadi.

b. Segmentasi pasar koi kelas ternak

Untuk kelas koi ternak, maka segmentasi pasar yang digunakan dari sisi segmentasi geografis adalah wilayah-wilayah didaerah sekitar Blitar, Bantul, Mojokerto, Madiun, dan Brebes. Untuk daerah Bantul dan Mojokerto merupakan daerah mitra lama, sedangkan untuk daerah Madiun dan Brebes adalah daerah sasaran baru yang akan dijadikan target Mubin Koi Farm dalam menjual koi kelas ternak. Dari sisi segementasi demografis, ikan koi jenis ini hanya akan mentargetkan pada pembudidaya ikan koi melalui tambak dan 
kolam tanpa memperhitungkan grade dari koi tersebut. Sedangkan secara psikografis, maka jenis ini hanya akan ditujukan kepada para peternak / petani koi yang tidak memperhatikan aspek motif, warna dan panjang pada koi yang dipeliharanya.

\section{Market targeting}

Berdasarkan analisis segmentasi yang dilakukan, maka target pasar yang akan dilakukan oleh Mubin Koi Farm terdiri dari 2 kelompok yaitu:

a. Kelompok menengah keatas untuk koi jenis kontes dan hobi, dan

b. Kelompok menengah untuk koi jenis peternak

\section{Positioning}

Sedangkan sebagai identifikasi pasar, Mubin Koi Farm akan memposisikan dirinya sebagai salah satu pembudidaya koi yang memiliki jenis varians koi berbeda, baik untuk jenis kontes ataupun jenis ternak. Keunggulan yang dapat ditonjolkan dari Mubin Koi Farm adalah kualitas yang terjamin untuk koi-koi jenis kontes baik dari sisi warna, pola, dan panjangnya. Hal ini diperkuat dengan indukan koi yang dibeli langsung dari jepang dan tetap dijaga garis keturunannya baik keturunan murni ataupun hasil penyilangan. Gambar 4 merupakan jenis koi untuk kontes.

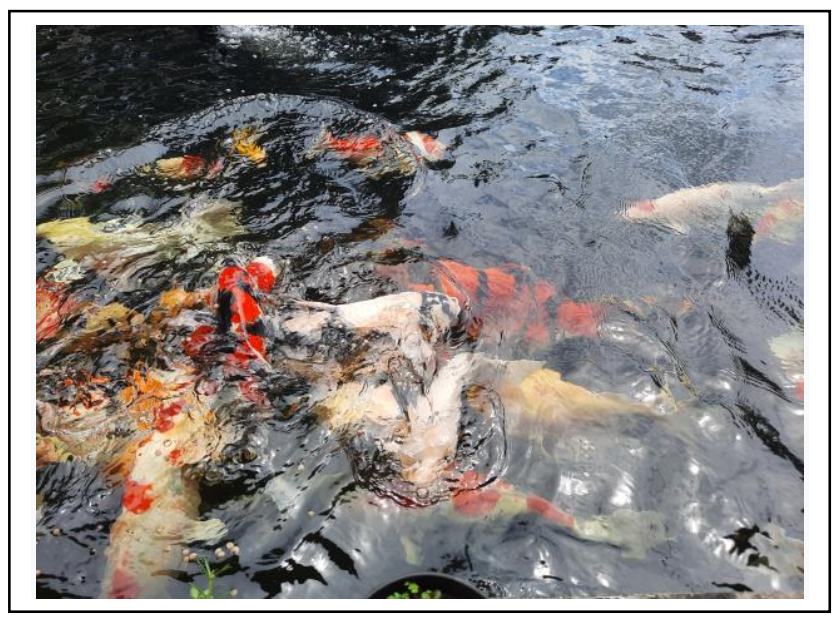

Gambar 4. Koi jenis kontes

Untuk koi ternak, Mubin Koi Farm juga akan memperhatikan kualitas pembibitan yang dilakukannya. Gambar 5 adalah gambaran kolam bibit koi untuk jenis koi ternak

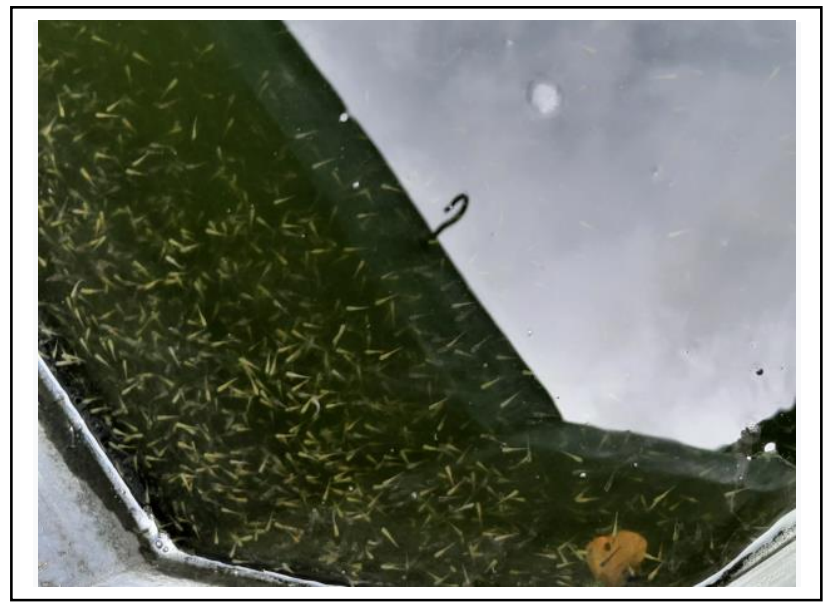

Gambar 5. Bibit koi jenis ternak 


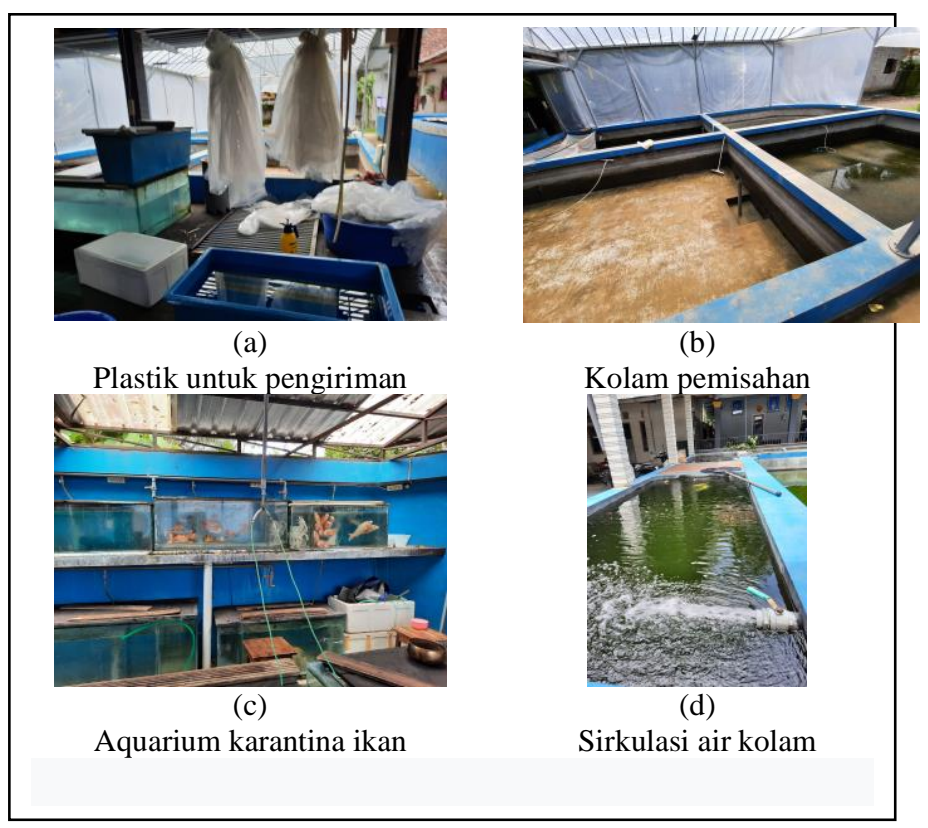

Gambar 6. Perlengkapan mubin koi farm

Untuk pelatihan desain pembuatan katalog digital kami akan menggunakan tool coreldraw. Target yang kami latih adalah seorang admin yang akan bertanggungjawab terhadap jenis promosi baik melalui media sosial maupun pembuatan katalog. Adapun kegiatan yang dilakukan terhadap admin tersebut adalah:

\section{Perubahan tampilan Instagram}

Sejak November 2020 postingan koi yang dilakukan pada nestkoi mulai dilengkapi dengan video mengenai koi yang akan dipasarkan, hal ini bertujuan untuk meyakinkan customer bahwa koi yang diperjualbelikan pada nestkoi adalah koi yang berasal dari tangan pertama penjual.

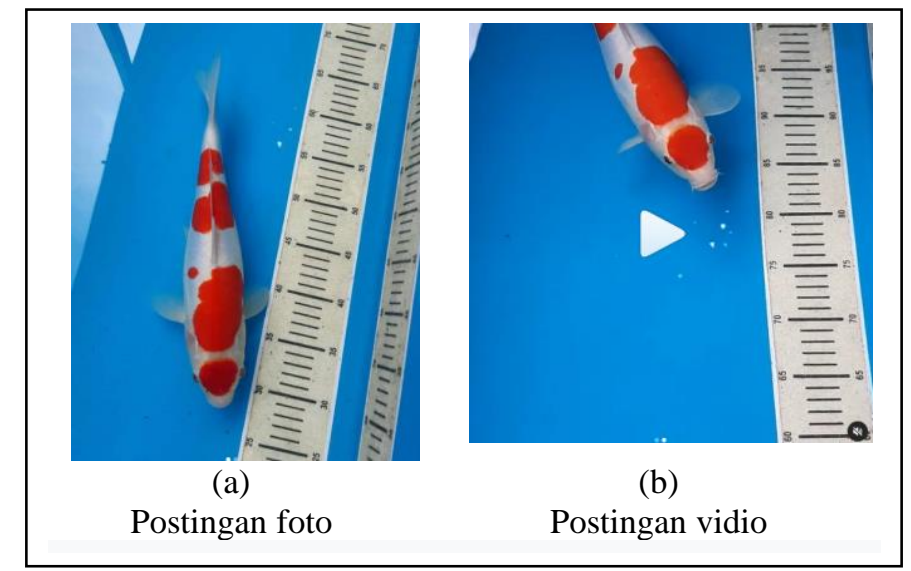

Gambar 7. Tampilan postingan Instagram nestkoi

\section{Pelatihan desain katalog online}

Untuk kegiatan desain katalog, kami akan menggunakan aplikasi coreldraw dan canva dalam mendesain. Pelatihan akan dilakukan selama 1 bulan. Pada tahapan awal, admin akan diperkenalkan terhadap perbedaan dari kedua applikasi tersebut yang selanjutnya akan dikenalkan fitur-fitur dasar pada keduanya. 
Sebagai tolak ukur keberhasilan kegiatan yang dilakukan, kami menggunakan pengukuran secara peningkatan jumlah pesanan koi dan pemahaman admin terhadap pelatihan yang diberikan. Untuk strategi market, kami belum memiliki hasil yang signifikan, karena masih 2 bulan sejak strategi tersebut diterapkan. Tetapi diharapkan setelah dilakukannya STP (segmentation, Targeting, dan Positioning) dapat menaikkan jumlah pemesanan koi baik koi jenis kontes ataupun jenis ternak pada Mubin Koi Farm.

Sedangkan dari sisi pelatihan desain katalog, didapatkan bahwa adanya peningkatan pengetahuan bagi admin dalam mendesain katalog jenis koi, serta pemasaran melalui media sosial terhadap penjualan. Rangkuman mengenai tolak ukur keberhasilan ini terlihat pada gambar 8 .

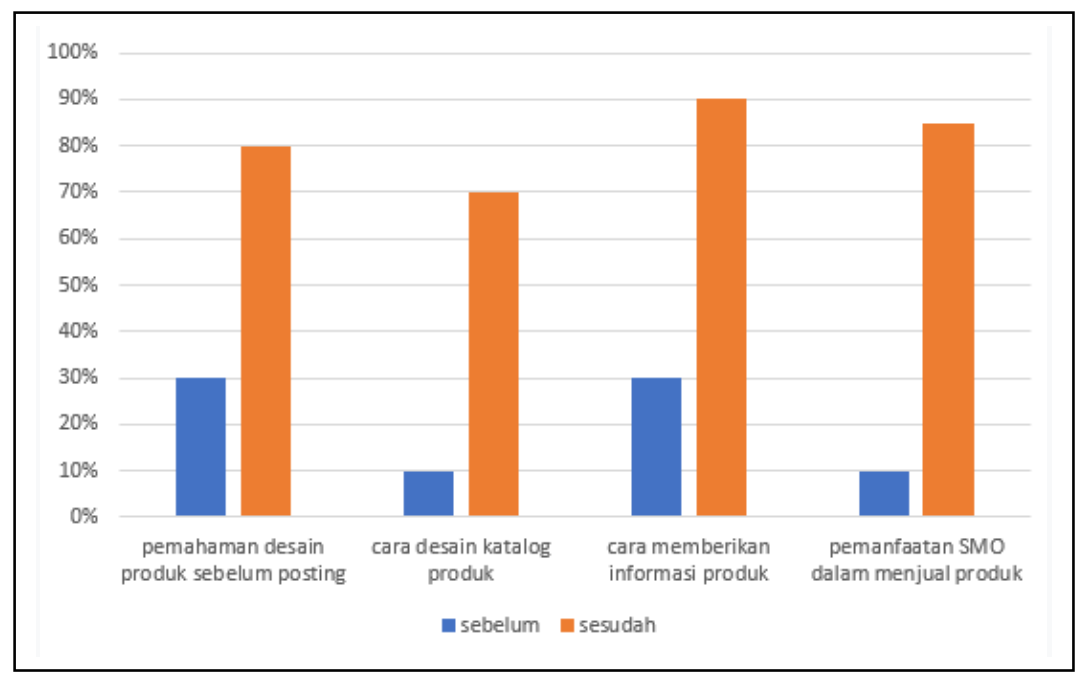

Gambar 8. Evaluasi kegiatan pelatihan desain

\section{KESIMPULAN}

Berdasarkan kegiatan yang dilakukan, didapatkan bahwa untuk jenis koi kontes dan peternak memiliki segmentasi pasar yang berbeda dimana untuk segementasi pasar jenis kontes lebih ditujukan kepada kota-kota besar yang selalu mengadakan kontes ikan hias karena tergetting dari segementasi ini adalah para pecinta ikan hias. Sedangkan dari sisi jenis koi peternak, target dari segmentasi pasarnya adalah daerah-daerah yang memiliki pembudidaya ikan koi besar. Untuk mendukung segementasi yang dilakukan maka kegiatan ini juga membekali pegawai Mubin Koi untuk dapat mendesain catalog dari jenis ikan yang dimiliki. Setelah dilakukan Analisa terhadap kegiatan yang dilakukan maka didapatkan hasil bahwa terdapat peningkatan pengetahuan terhadap pegawai Mubin Koi dalam mendesain catalog serta pengoptimalan promosi melalui media social yang dilakukan.

\section{DAFTAR PUSTAKA}

Abdullah, Y., Rosliyati, A., \& Nugraha, W. A. (2020). Strategi Internet Marketing Pada Bisnis Kuliner Di Komunitas Wisata Tasikmalaya. Jurnal Riset Manajemen Dan Bisnis (JRMB), 5(1), 209-220.

Albab, M. U. (2012). 8 Produk Unggulan Kota Blitar. http://mualbab.blogspot.com/2012/04/8produk-unggulan-kota-blitar.html

Bukit, F. R. A., A.S, G. G., Irvan, I., \& Fahmi, F. (2019). Pembuatan Website Katalog Produk Umkm Untuk Pengembangan Pemasaran Dan Promosi Produk Kuliner. Jurnal $\begin{array}{lllll}\text { Pengabdian Dan } & \text { Pemberdayaan } & \text { Masyarakat, } & 3(2) .\end{array}$ 
https://doi.org/10.30595/jppm.v3i2.4317

Hakiki, M. A. (2020). Penerapan Efektivitas Segmentasi Pasar Terhadap Peningkatan Volume Penjualan UD . Bitang Timur Di Desa Sumber Pakem Kecamatan Sumber Jambe Kabupaten Jember. Lan Tabur: Jurnal Ekonomi Syari'ah, 1(2), 148-160. https://doi.org/https://doi.org/10.1234/lan\%20tabur.v2i2.3650

Harliana, H., Setiadi, R., Bachri, O. S., Iskandar, K., \& Prasetya, G. (2020). Pemanfaatan ECommerce Terhadap Penjualan Kendang Jimbe Blitar. Jurnal Abdi Masyarakat UMUS (JAMU), 1(01), 15-20.

Oktaviandi, R. (2020). Analisis Strategi Pemasaran Ikan Pada Kelompok Tani Sugoi's $\begin{array}{lllll}\text { Kabupaten Sukabumi. } & \text { Syntax } & \text { Idea, } & \text { 2(10), } & \text { 1-9. }\end{array}$ https://doi.org/https://doi.org/10.36418/syntax-idea.v2i10.653

Pemerintah Kota Blitar. (2019). Gambaran Umum Kota Blitar. https://www.blitarkota.go.id/index.php/id/halaman/gambaran-umum

Pemerintah Kota Blitar. (2020). Sukses Kenalkan Komoditas, Pemkot Blitar Berpeluang Ekspor Tiga Produk Unggulan. Situs Resmi Pemerintahan Kota Blitar. https://blitarkota.go.id/id/berita/sukses-kenalkan-komoditas-pemkot-blitar-berpeluangekspor-tiga-produk-unggulan

Putri, L., \& Saifuddin, M. (2020). Implementasi Strategi Promosi Produk dalam Proses Keputusan Pembelian Melalui Digital Marketing Saat Pandemi Covid'19. Jurnal Manajemen Dan Inovasi (MANOVA), 2(2), 23-31. https://doi.org/https://doi.org/10.15642/manova.v3i2.301

Rozsidhy, D. H., \& Pribadi, J. D. (2018). Pembuatan E-Katalog Produk Di Facebook Sebagai Sarana Promosi Untuk Meningkatkan Penjualan Dengan Menggunakan Aplikasi Paint Tool SAI dan Adobe Photoshop di Resto Ayam Bacem Bakar Gribig Malang. JAB: Jurnal Aplikasi Bisnis, 4(2).

Sadiyah, K., Septiningrum, L. D., Hasan, J. M., Gustiasari, D. R., \& Darsita, I. (2020). Pengenalan Digital Marketing Dalam Upaya Meningkatkan Penghasilan Ibu Rumah Tangga (IRT) Majlis Taklim Al Auladiyah. Dedikasi PKM Unpam, 1(3), 1-8. 